\title{
MOŻLIWOŚCI ROZWIĄZANIA PROBLEMÓW LOGISTYKI MIEJSKIEJ W OBSZARZE INFRASTRUKTURY DROGOWEJ NA PRZYKŁADZIE KONSTANTYNOWA ŁÓDZKIEGO
}

\author{
POSIBILITEIES OF SOLVING URBAN LOGISTICS PROBLEMS \\ IN THE ROAD INFRASTRUCTURE \\ IN CASE OF KONSTANTYNOW LODZKI
}

\begin{abstract}
NR DOI: $10.25167 / \mathrm{sm} 2018.030 .01 \quad$ s. $9-24$
ABSTRAKT: Konstantynów Łódzki jest częścią Łódzkiego Obszaru Metropolitalnego i ma prawie 18 tys. mieszkańców. Jego położenie powoduje, że jest popularnym miejscem osiedlania się osób pracujących w Łodzi. Miasto połączone jest z Łodzią linią tramwajową oraz kilkoma drogami łączącymi je z centrum aglomeracji oraz przenoszącymi ruch w relacji północ-południe. Obecnie infrastruktura drogowa jest najważniejszym elementem dającym możliwość przemieszczania się mieszkańców. Taka sytuacja powoduje szereg problemów transportowych. Celem artykułu jest zaproponowanie rozwiązania problemów logistyki transportu drogotwego Konstantynowa Łódzkiego. Na podstawie danych z badań ruchu drogowego oraz analizy istniejącej infrastruktury transportowej dokonano prognozy ruchu drogowego do $2040 \mathrm{r}$. Prognoza ta oraz szereg innych czynników pozwoliły na nakreślenie niezbędnych zmian w infrastrukturze transportowej, które dają szansę na rozwiązanie istniejących i narastających problemów w obszarze logistyki miejskiej Konstantynowa Łódzkiego.
\end{abstract}

SŁOWA KLUCZOWE: infrastruktura drogowa, logistyka miejska, planowanie przebiegu obwodnic

ABSTRACT: Konstantynów Łódzki is part of the Łódź Metropolitan Area, with almost 18 thousand residents. Its location causes it to be a popular place of settlement for people working in Łódź. The city is connected by a tram line with Łódź and several roads connecting them with the center of the agglomeration and transferring traffic in the north-south direction. Currently, the road infrastructure is the most important element that gives residents the possibility of moving around. This situation causes a number of transportrelated problems. The aim of the article is to propose a solution to the problems faced by the road transport logistics in Konstantynów Łódzki. Based on data from road traffic studies and analyses of the existing trans-

* Uniwersytet Łódzki, Wydział Zarządzania, Katedra Logistyki, Zakład Zastosowania Nowoczesnych Technologii w Logistyce, e-mail: remigiusz.kozlowski@uni.lodz.pl

** Uniwersytet Łódzki, Wydział Nauk Geograficznych, Instytut Zagospodarowania Środowiska i Polityki Przestrzennej, Zakład Polityki Przestrzennej, e-mail: szymon.wisniewski@geo.uni.lodz.pl

*** Uniwersytet Łódzki, Wydział Zarządzania, Katedra Logistyki, Zakład Zastosowania Nowoczesnych Technologii w Logistyce, e-mail: anna.m.palczewska@gmail.com 
port infrastructure, a forecast relating to traffic until 2040 was made. This forecast and a number of other factors allowed outlining the necessary changes in the transport infrastructure, which give an opportunity to solve the existing and growing problems in the area of Konstantynów Łódzki's urban logistics.

KEY WORDS: road infrastructure, urban logistics, planning of bypass routes, Konstantynów Łódzki

\section{Wprowadzenie}

W Polsce nadal istnieje problem niedorozwoju infrastruktury drogowej. Pod tym względem dzieli nas duży dystans do np. krajów Europy Zachodniej. Przynależność Polski do Unii Europejskiej daje szansę na pozyskanie środków na budowę dróg, co $\mathrm{w}$ konsekwencji powinno doprowadzić do zniwelowania dysproporcji w poziomie rozwoju gospodarczego.

Bardzo istotne jest także odpowiednie zaplanowanie przebiegu poszczególnych elementów infrastruktury transportowej. W tym celu należy przeprowadzić szereg badań, dzięki którym możliwe stanie się znalezienie zarówno optymalnego przebiegu dróg, jak również prawidłowych ich parametrów. Należy pamiętać, że zbudowanie infrastruktury transportu w sposób nieodpowiedni skutkuje negatywnymi konsekwencjami dla realizacji procesów logistyki. W efekcie miasta, aglomeracje czy też obszary metropolitalne funkcjonują gorzej, niż mogłyby, gdyby nie popełniono błędów na etapie planowania infrastruktury transportu.

W niniejszym artykule wykorzystano dane z raportu końcowego projektu „Systemowe wsparcie procesów zarządzania w JST" współfinansowanego przez Unię Europejską ze środków Europejskiego Funduszu Społecznego w ramach Programu Operacyjnego Kapitał Ludzki, Priorytet V, Działanie 5.2, Poddziałanie 5.2.2, opracowanego dla Konstantynowa Łódzkiego przez zespół ekspertów z Wydziału Zarządzania Uniwersytetu Łódzkiego w składzie: dr hab. Remigiusz Kozłowski, prof. UŁ, dr hab. Michał Marczak, prof. UMED, dr Andrzej Sikorski, mgr Tomasz Kozal, mgr Artur Janusz i mgr Anna Palczewska. Celem artykułu jest zaproponowanie rozwiązania problemów logistyki transportu drogowego miasta Konstantynów Łódzki należącego do Łódzkiego Obszaru Metropolitalnego.

\section{Znaczenie infrastruktury drogowej dla sprawnej komunikacji w obszarach metropolitalnych}

Nieefektywne funkcjonowanie podsystemów związanych z transportem i łącznością zazwyczaj pociąga za sobą szeroki wachlarz negatywnych konsekwencji dla pozostałych podsystemów wchodzących w skład organizmu miejskiego. W literaturze przedmiotu (Brol (red.) 2004) spotkać można bogaty zestaw tego rodzaju skutków: spowolnienie rozwoju gospodarczego, wycofywanie zainwestowanego kapitału, brak nowych inwestycji, wzrost kosztów i obniżenie jakości procesów logistycznych. Co więcej, liczba problemów transportowych miasta wydaje się systematycznie rosnąć. Zarządcy muszą radzić sobie m.in. z brakiem obwodnic, bezkolizyjnych skrzyżowań, 
co w konsekwencji skutkuje koniecznością obsługi ruchu tranzytowego przez centra miast. Za I. Dembińską-Cyran (2006) należy podkreślić, że negatywna sytuacja pogłębia się w wyniku braków systematycznego planowania systemów transportowych, a szerzej: kreowania polityk transportowych. Istotnym czynnikiem wpływającym na kierunek rozwoju miejskich systemów transportowych jest wzrastająca świadomość zagrożeń ekologicznych związanych z funkcjonowaniem transportu. Edukacja proekologiczna, a przede wszystkim czynniki prawne i administracyjne, zmuszają władze lokalne do stosowania ograniczeń dla transportu. Działania w tym kierunku zapoczątkowano już w latach 90. XX w. i odniesiono je na równi do transportu pasażerskiego, jak i towarowego. Badania z tego zakresu (Perenc 1994) wskazują na szeroki wachlarz rozwiązań problemów transportowych miasta. Mając na uwadze, że każda jednostka charakteryzuje się niepowtarzalną kombinacją uwarunkowań rozwoju i funkcjonowania, należy każdorazowo stosować podejście indywidualne, oparte na wypracowanych wcześniej dobrych praktykach. J. Perenc (1994) wskazuje m.in. na zmiany w kierunku ekonomiczności, ochrony środowiska, optymalizacji obciążenia sieci ulic poprzez maksymalne wykorzystanie ekologicznych pojazdów.

Jeśli wskazane powyżej propozycje przemian zostaną zrealizowane, a ponadto jeśli wystąpi między nimi zjawisko synergii, to można założyć, że organizm miejski będzie systematycznie niwelował dręczące go problemy w zakresie funkcjonowania transportu. Należy jednocześnie pamiętać, że wprowadzenie nowych elementów infrastruktury (np. drogowej) ma szansę stanowić czynnik wpływający nie tylko w sposób pozytywny na działanie miasta. Trzeba w tym miejscu wspomnieć np. o: ruchu wzbudzonym, chaotycznym rozlewaniu się miasta, separacji przestrzeni, degradacji terenów cennych przyrodniczo, wzroście poziomu hałasu i zanieczyszczeń (Wiśniewski 2016).

Zgodnie z badaniami Z.K. Zuziaka (2008) system transportowy należy rozpatrywać, począwszy od jego formułowania, poprzez definiowanie potrzeb i kontaktów aż do identyfikacji konfliktów. Z kolei spełnienie potrzeby mobilności w ośrodku miejskim wymaga realizacji przemieszczania się osób i ładunków (Rudnicki 2010). Mówiąc o sferze transportowej, należy miasto postrzegać jako przestrzeń kontaktów społecznych, wymiany informacji i cyrkulacji środków produkcji. W tym ujęciu jest to też źródło konfliktów mających swoje podłoże w „walce” o dostęp do przestrzeni komunikacyjnej czy antagonizmów wynikających z uciążliwości transportu dla otoczenia. Według S. Marshalla i D. Banistera (eds., 2007) głównym zadaniem stojącym przed miejską polityką transportową jest wskazanie kierunku pozytywnych przemian $\mathrm{w}$ planowaniu przestrzennym nastawionych na wzmacnianie procesu osiągania stanu zrównoważonego transportu miejskiego. Wiąże się to niewątpliwie z licznymi barierami instytucjonalnymi, legislacyjnymi, finansowymi, społecznymi i kulturowymi. Jak zwykle jednak w przypadku gospodarowania przestrzenią dominującym problemem jest zintegrowanie polityki z działaniami na szczeblu operacyjnym i włączenie interesów różnych interesariuszy. Ocenę efektywności funkcjonowania miejskiego systemu transportowego wystawia w tym zakresie poziom współzależności struktury przestrzennej miasta i układu transportu. 
Zaprezentowana przez T. Komornickiego i in. (2013) analiza rozkładu „wąskich gardeł" systemu drogowego podkreśla, że usprawnienie funkcjonowania systemu transportowego i wzrost poziomu bezpieczeństwa każdego z użytkowników sieci jest wynikiem w znacznej mierze separacji ruchu lokalnego od przejazdów o charakterze tranzytowym. Są to oczywiście jedynie dwie główne zalety implementacji do lokalnego systemu transportowego założeń obwodnicowych. Komornicki (2015) wskazuje również, że modernizacja oraz budowa nowych odcinków sieci drogowej jest aktualnie zadaniem kluczowym dla zrównoważonego rozwoju społeczno-gospodarczego. Odwołując się do wspomnianej wcześniej tematyki zrównoważonego rozwoju systemów transportowych, należy wymienić w tym nurcie inwestycje w transport publiczny, rowerowy i pieszy oraz integrację różnych środków transportu (węzły przesiadkowe, parkingi P\&R itd.).

Często zakładanym rezultatem inwestowania $\mathrm{w}$ infrastrukturę drogową jest skrócenie czasu przejazdu. J. Cheng i L. Bertolini (2013) podkreślają towarzyszący temu procesowi wzrost poziomu dostępności poszczególnych elementów zagospodarowania przestrzeni czy form ludzkiej aktywności. Zniwelowanie zjawiska kongestii poprzez likwidację „wąskich gardeł” w systemie transportowym może zostać uzyskane poprzez konsekwentne podnoszenie parametrów infrastruktury oraz włączanie do systemu coraz bardziej efektywnych rozwiązań z zakresu organizacji ruchu (np. obszarowe systemy sterowania ruchem). Komornicki i in. (2013) wskazują, że elementy te przekładają się, w różnym rzecz jasna stopniu, na wzrost satysfakcji społeczeństwa, na skutek poprawy dostępu do usług publicznych oraz zwiększenia poziomu bezpieczeństwa ruchu drogowego.

Lokalny system transportowy, złączony efektywnie z systemem ponadregionalnym, pozwala na skuteczne wyprowadzenie ruchu (przede wszystkim towarowego), którego generatorami są rozmieszczone w przestrzeni miasta działalności gospodarcze zajmujące się produkcją, magazynowaniem czy dystrybucją (Wiśniewski 2016). Powiązania transportowe tychże punktów w mieście powinny być skierowane do najbliższego węzła drogowego. A wynikać to powinno nie z zakazu przejazdu przez miasto pojazdów realizujących tranzyt, ale z dostrzegalnego przez kierowców i spedytorów zysku czasowego i kosztowego.

W tym względzie zasadniczą kwestią jest rozmieszczenie „przecięć” lokalnych dróg siecią regionalną (Wiśniewski 2016). Można bowiem przyjąć, że część lokalnego ruchu przy korzystnie rozmieszczonych punktach włączenia w obwodnicę wykorzysta ją, aby dotrzeć do punktu w przestrzeni samego miasta. W tym względzie nawet niewielkie braki kluczowych odcinków dróg o wysokich parametrach czy ich niefortunne połączenie z siecią lokalną mogą niwelować pozytywny efekt innych inwestycji lokalnych związanych bezpośrednio lub pośrednio z siecią transportową.

Ma to duże znaczenie w świetle przewidywanego przez Komornickiego i in. (2013) wyludniania się obszarów peryferyjnych i wzrostu znaczenia suburbanizacji w największych aglomeracjach. Procesy te bowiem będą wpływać na zmiany natężenia ruchu, a ich przyspieszenie należy utożsamiać ze sprawnie funkcjonującymi systemami transportowymi. 
Rozważane w niniejszym opracowaniu inwestycje infrastrukturalne mają szczególnie znaczenie w kontekście kształtujących się obszarów metropolitalnych czy miejskich obszarów funkcjonalnych. Jeśli chodzi o obszar metropolitalny, to wyprowadzenie ruchu tranzytowego czyni sprawniejszymi wszelkie połączenia funkcjonalne poszczególnych gmin. Doskonałym przykładem może być tu podkreślona w ustawie metropolitalnej organizacja transportu zbiorowego. Współdziałanie podmiotów wchodzących w skład systemu logistycznego miasta nie może przebiegać odpowiednio efektywnie, jeśli nie będzie sprawnie działającej infrastruktury. Są one jednym z czynników, dzięki którym możliwe jest tworzenie się klastrów logistycznych (Kozłowski 2011). Klastry te są jednym z ważnych czynników rozwoju gospodarczego.

\section{Charakterystyka Konstantynowa Lódzkiego i jego systemu transportowego}

Miasto Konstantynów Łódzki położone jest w powiecie pabianickim w województwie łódzkim na zachód od Łodzi nad rzeką Ner. Wchodzi w skład aglomeracji łódzkiej wraz z: Łodzią, Zgierzem, Pabianicami, Aleksandrowem Łódzkim, Rzgowem, Ozorkowem, Głownem, Koluszkami, Brzezinami, Tuszynem i Strykowem. Jego powierzchnia wynosi $26,87 \mathrm{~km}^{2}$. Powstanie miasta było związane z rozwojem włókiennictwa w rejo-

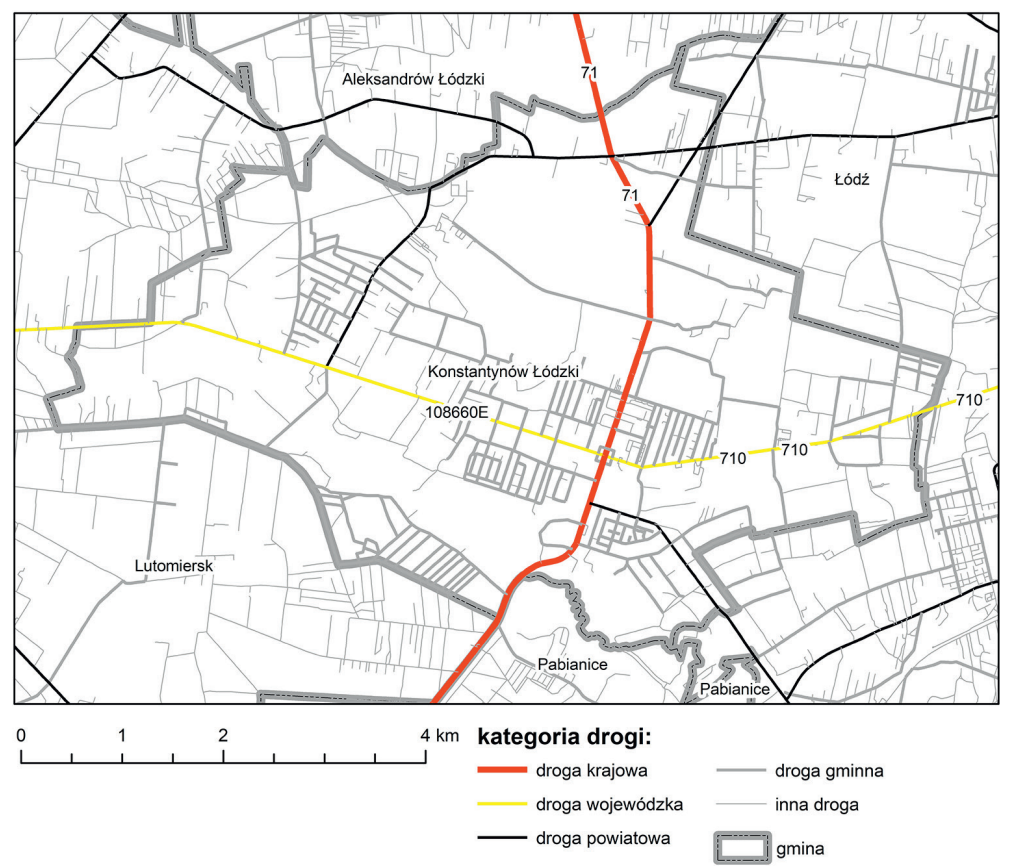

Ryc. 1. Granice miasta Konstantynów Łódzki wraz z głównymi drogami Źródło: opracowanie własne. 


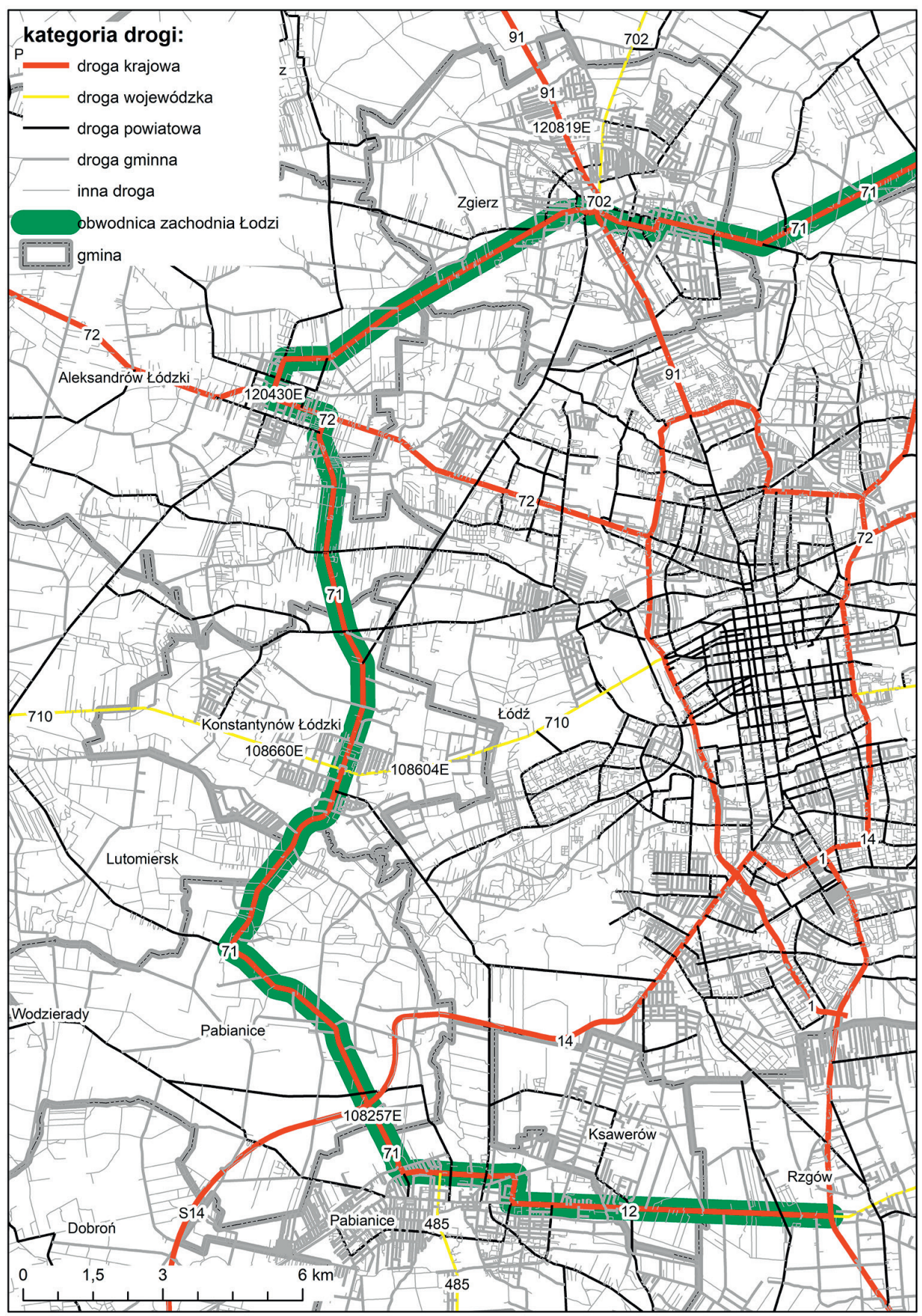

Ryc. 2. Obwodnica zachodnia miasta Łodzi w postaci drogi 71 biegnącej przez Konstantynów Łódzki Źródło: opracowanie własne. 
nie Łodzi (Konstantynów, twoje miasto). Miejscowość powstała na terenie wsi Żabice Wielkie w 1824 r., kiedy to nadano miastu dziś znaną nazwę. Prawa miejskie uzyskało w 1830 r., następnie ponownie w 1924 r., na skutek ich utraty w 1870 r. Miasto zostało zniszczone w czasie pierwszej wojny światowej.

Miejscowość Konstantynów Łódzki posiada 17878 mieszkańców według danych GUS za 2016 r. W tym samym roku suma dochodów budżetu miasta wyniosła 47,3 mln złotych. W przeliczeniu na jednego mieszkańca było to 2,7 tys. (Konstantynów Łódzki w liczbach). Przychody z transportu i łączności, w tym z tytułu podatku od środków transportu, wyniosły 0,1\% dochodu całego budżetu w 2014 r. (Statystyczne vademecum samorządowca). Obecnie przez miasto oprócz dróg powiatowych i gminnych przebiegają drogi: wojewódzka nr 710 oraz krajowa nr 71 (ryc. 1 i ryc. 2).

Ryciny 3 i 4 pokazują, jak wolno poruszają się pojazdy w Konstantynowie Łódzkim na tych drogach w stosunku do pozostałych części miasta. Na ryc. 3 widać, że ruch odbywa się bardzo wolno na drogach 71 i 710 w kierunku centrum.

Na zamieszczonych powyżej mapach widać, że prędkości pojazdów w godzinach porannych w poniedziałki w Konstantynowie Łódzkim są znacznie niższe od prędkości odnotowanych w piątki, w pozostałych dniach kształtują się one na podobnym poziomie we wskazanym przedziale godzinowym. Drugą cechą charakterystyczną

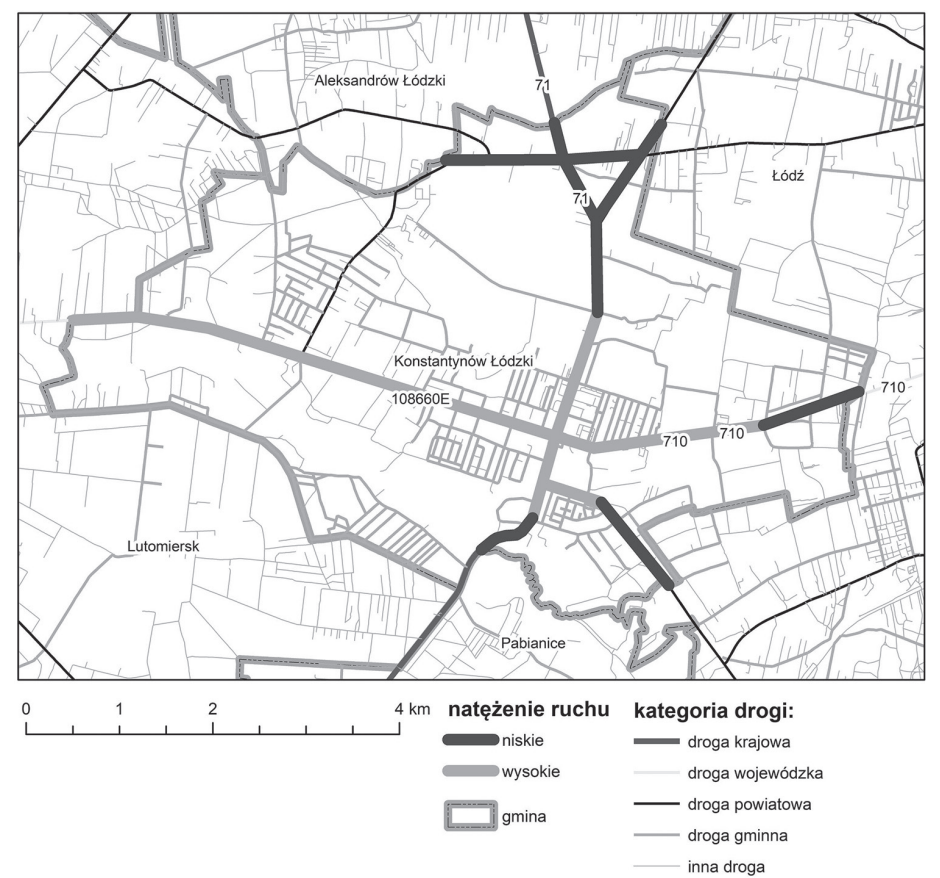

Ryc. 3. Typowe natężenie ruchu w piątek o godz. 15.25 w centrum miasta na skrzyżowaniu dróg 71 i 710

Źródło: opracowanie własne na podstawie Google Maps (dostęp 5 sierpnia 2016). 


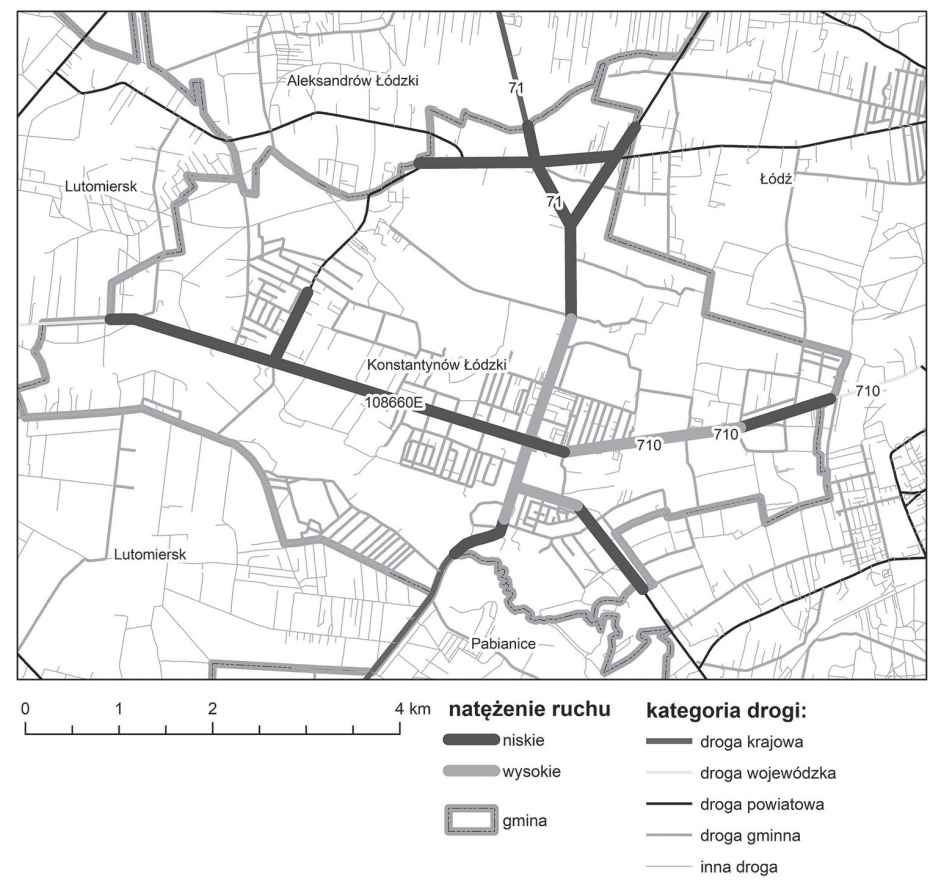

Ryc. 4. Typowe natężenie ruchu w poniedziałek o godz. $7.35 \mathrm{w}$ centrum miasta na skrzyżowaniu dróg 71 i 710

Źródło: opracowanie własne na podstawie Google Maps (dostęp 5 sierpnia 2016).

jest bardzo wolne poruszanie się pojazdów do i z centrum. Natężenie ruchu w mieście w godzinach $7.30-10.00$ oraz $15.00-18.00$ jest duże. Z uwagi na bliskość Łodzi można przyjąć, że godziny szczytów w mieście pokrywają się z godzinami wskazanymi w Raporcie o korkach w 7 największych miastach Polski z 2016 r., który wskazuje właśnie na te przedziały czasowe jako pory o największym natężeniu ruchu w Łodzi (Rzepnikowska et al. 2016).

\section{Problemy komunikacyjne analizowanego miasta}

Do analizy sytuacji na drogach w Konstantynowie Łódzkim wykorzystano dane z następujących dokumentów: Generalny pomiar ruchu w 2010 r., Pomiar ruchu na drogach wojewódzkich w 2010 r., Pomiar ruchu na drogach powiatowych powiatu pabianickiego - rok 2013.

$\mathrm{Z}$ analizy zarówno tych dokumentów, jak i natężenia ruchu na podstawie Google Maps (ryc. 3 i ryc. 4) wynika, że centrum Konstantynowa Łódzkiego jest obciążone bardzo dużym ruchem samochodowym. Analizując bardziej szczegółowe dane pomiaru średniego dobowego ruchu (ŚDR) (por. ryc. 5), wyraźnie widać, że np. na pl. Tadeusza Kościuszki krzyżują się dwa potoki ruchu w układzie N-S i W-E, których suma 


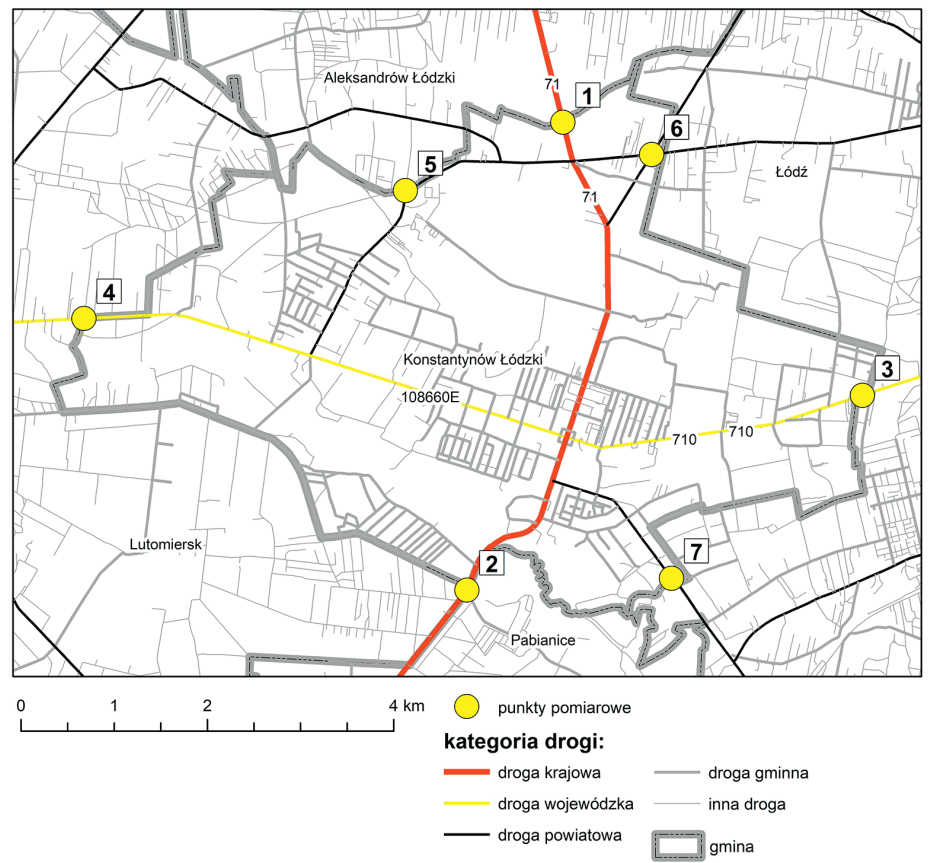

Ryc. 5. Dane ŚDR dla Konstantynowa Łódzkiego w 2013 r.

Źródło: opracowanie własne na podstawie: Kozłowski et al. 2014, s. 10

wynosi ok. 20 tys. pojazdów na dobę. Wynik ten jest porównywalny do przeciętnego obciążenia ruchem na średnio ruchliwych odcinkach polskich autostrad - za przykład może posłużyć węzeł A2 Emilia i Piątek. Jako efekt tego ruchu eksperci przywołali kongestię występującą w godzinach szczytów porannego i popołudniowego (Kozłowski et al. 2014).

Rycina 5 przedstawia siedem najistotniejszych pod względem komunikacyjnym miejsc Konstantynowa Łódzkiego. Do każdego z tych punktów w tabeli 1 podano średniodobową liczbę pojazdów.

Komunikacja pomiędzy Konstantynowem Łódzkim a innymi miastami w Łódzkim Obszarze Metropolitalnym wymaga poprawy (Kozłowski et al. 2014). Komunikacja z Łodzią opiera się na drodze wojewódzkiej DW710 w dojazdach do centrum Łodzi lub na drogach powiatowych w dojazdach do jej północnych i południowych dzielnic. Dojazd do Aleksandrowa Łódzkiego, Zgierza i Pabianic odbywa się przy wykorzystaniu drogi krajowej DK71.

Szczególnym czynnikiem, który trzeba brać pod uwagę, planując infrastrukturę drogową w Konstantynowie Łódzkim, jest oczekiwane wybudowanie drogi ekspresowej S14. Droga ta z jednej strony usprawni transport w kierunku północ-południe (Aleksandrów Łódzki, Zgierz i Pabianice), a z drugiej ograniczy możliwości rozwoju układu transportowego w relacji wschód-zachód z uwagi na to, że wjazd na S14 będzie 
Tabela 1

Średni dobowy ruch w miejscach dokonania pomiaru w Konstantynowie Łódzkim w 2013 r.

\begin{tabular}{|c|l|c|}
\hline Punkt & \multicolumn{1}{|c|}{ Ulica } & $\begin{array}{c}\text { Pojazdy samochodowe } \\
\text { (liczba ogółem) }\end{array}$ \\
\hline 1 & Aleksandrowska & 10030 \\
2 & Łaska & 8395 \\
3 & Łódzka & 10463 \\
4 & Lutomierska & 11620 \\
5 & Klonowa & 1174 \\
6 & Zgierska & 3386 \\
7 & 1 Maja & 5882 \\
\hline
\end{tabular}

Źródło: Kozłowski et al. 2014, s. 10.

możliwy tylko na dwóch węzłach. Planowane są na S14 cztery wiadukty pozwalające na przejazd pod i nad tą drogą ekspresową. Rycina 6 przedstawia ogólny schemat ideowy tego układu komunikacyjnego.

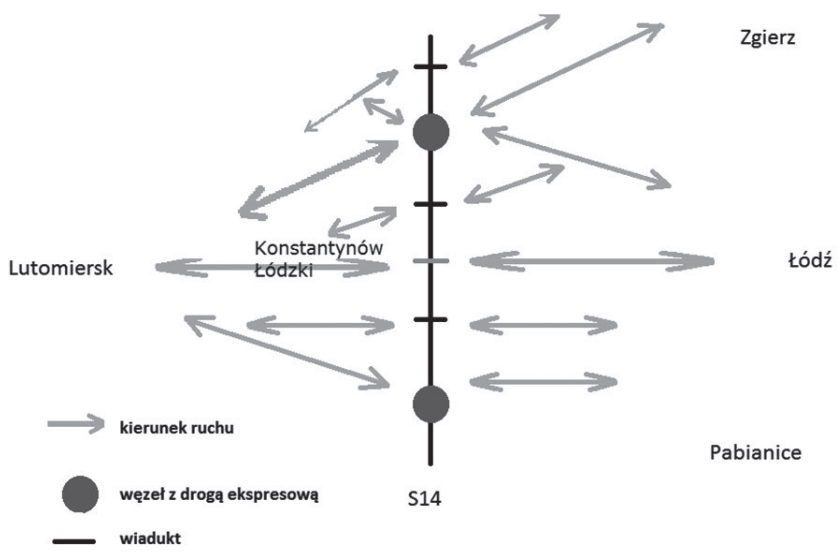

Ryc. 6. Schemat budowy S14 na odcinku miasta Konstantynów Łódzki Źródło: Kozłowski et al. 2014, s. 10.

\section{Prognoza ruchu pojazdów w wybranych punktach Konstantynowa Lódzkiego}

W celu rozwiązania problemów transportowych Konstantynowa Łódzkiego należy przede wszystkim uwzględnić prognozy ruchy na kolejne lata, które wskazują jednoznacznie, że będzie on ulegał zwiększeniu. W tej sytuacji należy pomyśleć o przebudo- 
waniu infrastruktury w taki sposób, aby umożliwiła przeniesienie ruchu poza centrum miasta lub nawet poza jego granice. I oczywiście należy uwzględnić również planowaną do realizacji infrastrukturę, a w szczególności drogę ekspresową S14.

Prognozy średniego dobowego ruchu dokonano na podstawie prognozy wzrostu PKB według danych Narodowego Banku Polskiego. Uwzględniono także dane Generalnej Dyrekcji Dróg Krajowych i Autostrad dla dróg krajowych oraz dane Urzędu Marszałkowskiego dla dróg wojewódzkich. Wyniki analiz zostały przedstawione na rycinie 7.

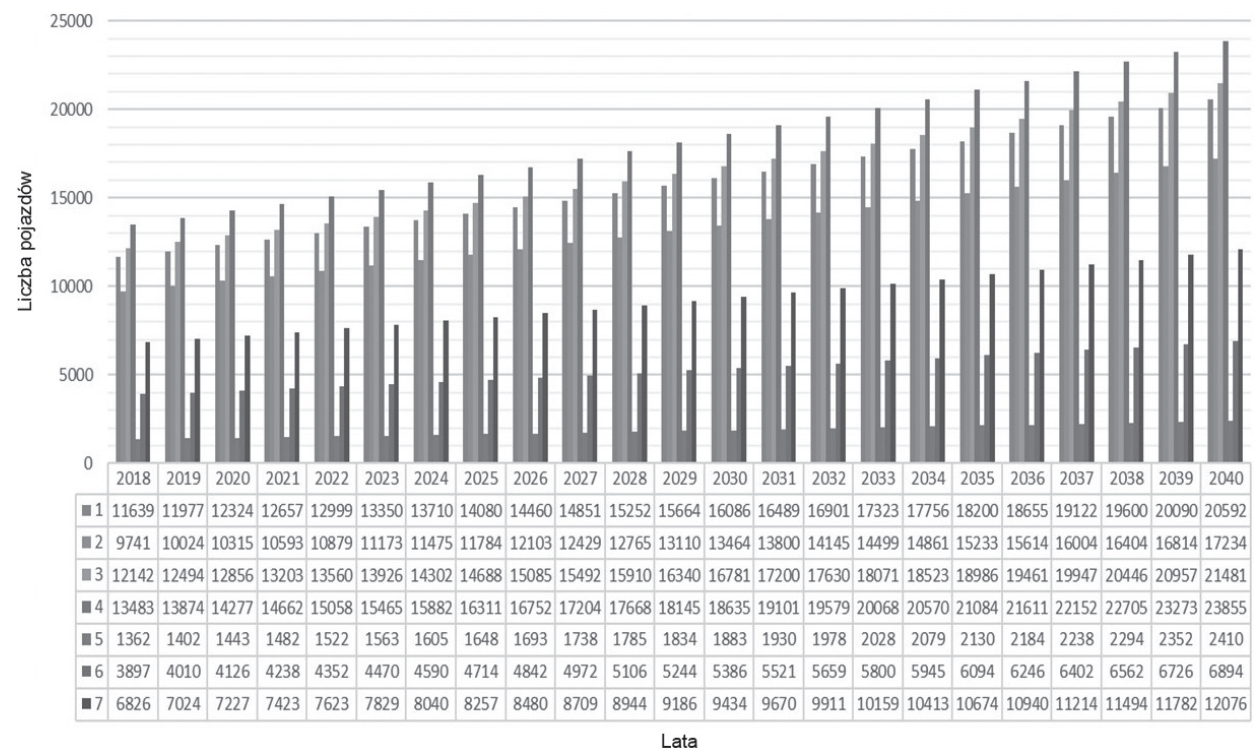

Ryc. 7. Prognoza średniego dobowego ruchu w analizowanych punktach pomiarowych 1-7 w przeliczeniu ogółem z uwzględnieniem przeliczników

Źródło: Kozłowski et al. 2014, s. 13.

Prognozy dokonane zostały dla najważniejszych z punktu widzenia logistyki miasta siedmiu punktów - tych samych, dla których zostały przedstawione wyniki badania ruchu w poprzednim podrozdziale. Prognozy przygotowano dla poszczególnych grup pojazdów, czyli: samochodów osobowych, dostawczych, ciężarowych (z wyodrębnieniem tych z przyczepami) oraz autobusów.

W kolejnych latach ruch w Konstantynowie Łódzkim wyraźnie wzrośnie. Obciążenie ruchem w poszczególnych punktach przy braku generalnej przebudowy drogi lub wprowadzenia odcinków odciążających ruch (obwodnicy) spowoduje ogromne przeciążenie obecnych dróg, które przekroczyłoby także akceptowalność społeczną. Sytuacja ta może doprowadzić do wydłużenia się czasu stania pojazdów w korku w godzinach szczytu, a w konsekwencji do rozciągnięcia się tego czasu (Kozłowski et al. 2014). 


\section{Propozycja rozwiązania problemów transportowych Konstantynowa Łódzkiego z uwzględnieniem prognozowanego ruchu pojazdów}

Rozwiązanie problemów komunikacyjnych badanego miasta skupia się na dwóch kierunkach działań:

1) rozbudowy infrastruktury drogowej i przepustowości istniejącego układu komunikacyjnego z uwzględnieniem budowy drogi ekspresowej S14,

2) usprawnienia systemu transportu pomiędzy Konstantynowem Łódzkim a miastami Łódzkiego Obszaru Metropolitalnego (ŁOM) ze szczególnym uwzględnieniem Łodzi.

Komunikacja pomiędzy Konstantynowem Łódzkim a miastami ŁOM ewidentnie wymaga poprawy. W przypadku Łodzi opiera się na wykorzystaniu DW710 w dojazdach do centrum tego miasta, ewentualnie dróg powiatowych w dojazdach do jego północnych i południowych dzielnic (odpowiednio ul. Zgierskiej-Szczecińskiej i ul. Kolejowej-Sanitariuszek). Komunikacja z Aleksandrowem Łódzkim, Zgierzem i Pabianicami opiera się na wykorzystaniu DK71.

Budowa drogi S14 usprawni transport w układzie północ-południe w obszarze ŁOM, a więc rozwiąże problemy z komunikacją pomiędzy Konstantynowem Łódzkim a Aleksandrowem Łódzkim, Zgierzem i Pabianicami. Efektem jej wybudowania będzie ograniczenie elastyczności rozwoju układu transportowego w układzie wschódzachód. Wjazd na S14 będzie możliwy tylko na dwóch węzłach. Planowane są cztery wiadukty pozwalające na przejazd pod/nad S14.

Wykonane prognozy ruchu pojazdów wskazują, że wybudowanie drogi ekspresowej S14 rozwiąże problem związany z występowaniem obecnie i w przyszłości uciążliwego ruchu na DK71. Po uruchomieniu S14 przejmie ona niemal w całości ruch z drogi krajowej. Znacznie bardziej skomplikowana sytuacja wystąpi w przypadku ruchu na kierunku wschód-zachód. W tym przypadku zgodnie z wynikami prognozy należy przyjąć, że ruch na drodze wojewódzkiej 710 będzie wzrastał. Konieczne jest zatem podjęcie działań zmierzających do jego przeniesienia z obecnych dróg na inne. Przeprowadzone badania wykazały, że duże natężenie ruchu na drodze 710 występuje także na zachodniej granicy Konstantynowa Łódzkiego. Oznacza to, że bardzo duży potok pojazdów wjeżdża do Konstantynowa od strony zachodniej i jedzie w kierunku Łodzi, czyli jest to typowy ruch tranzytowy. W tej sytuacji należy podjąć działania zmierzające do przeniesienia tego ruchu z centrum Konstantynowa, najlepiej w całości lub przynajmniej w znacznej części, na inne szlaki. Należy tu zastosować klasyczne rozwiązanie polegające na budowaniu obwodnic miasta po jego obrzeżach północnych i południowych - wtedy osiągnięto by następujące korzyści:

- odciążenie centrum miasta, co podniosłoby komfort życia mieszkańców oraz zapewniłoby lepsze warunki funkcjonowania komunikacji miejskiej i aglomeracyjnej,

- polepszenie dostępności komunikacyjnej miasta dające szansę na jego dalszy rozwój. 
Droga ekspresowa S14 wpływa na przebieg planowanych obwodnic Konstantynowa Łódzkiego. Zarówno w przypadku południowej, jak i północnej obwodnicy miasta należy wziąć pod uwagę możliwość podłączenia ich do węzłów na S14. Włączenie ruchu z tych obwodnic bezpośrednio do drogi ekspresowej stanowi bardzo dobre rozwiązanie z następujących powodów:

- pojazdy będą miały możliwość szybkiego przemieszczania się (z wykorzystaniem S14) w inne miejsca ŁOM, także położone wzdłuż S8, A1 i A2,

- zwiększy to w znaczący sposób dostępność transportową Konstantynowa Łódzkiego,

- przyczyni się również do uspokojenia ruchu w centralnej części miasta.

Na ryc. 8 wyznaczono propozycje obwodnic północnej i południowej Konstantynowa Łódzkiego.

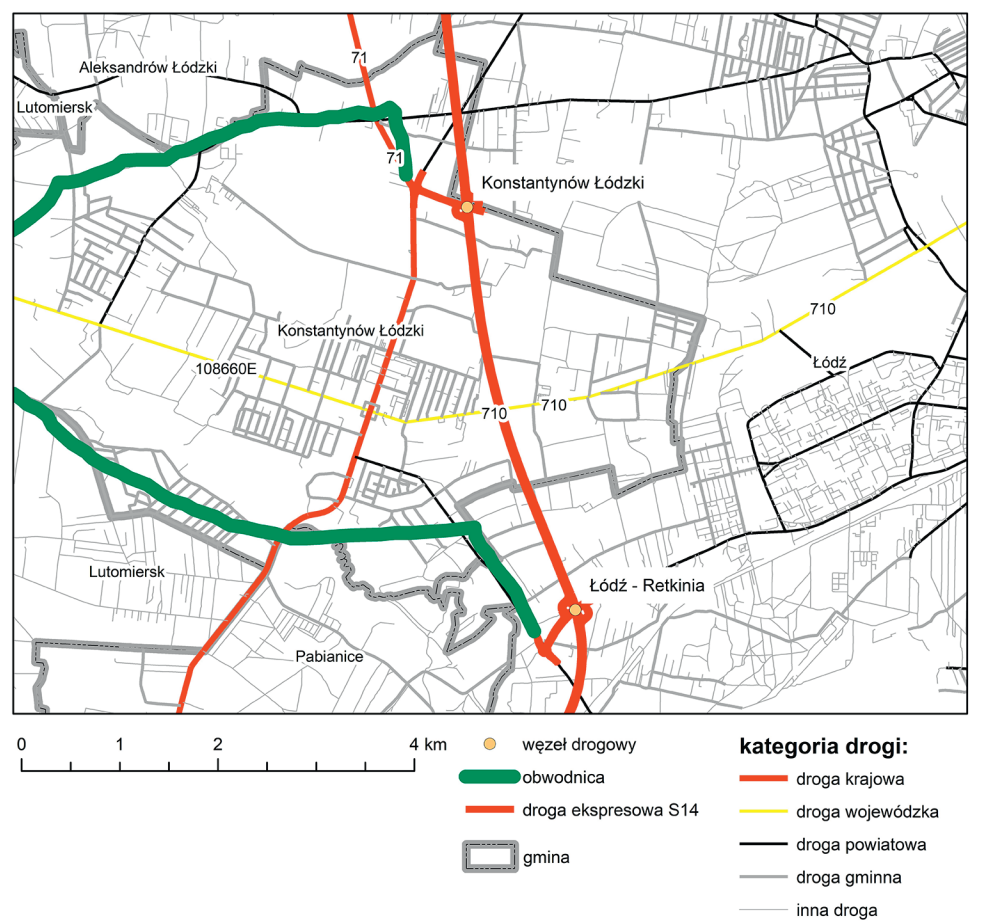

Ryc. 8. Proponowany przebieg obwodnic Konstantynowa Łódzkiego

Źródło: opracowanie własne na podstawie Kozłowski et al. 2014, s. 23.

Proponowana północna obwodnica zapewniłaby także dobre skomunikowanie z szybko rozwijającymi się terenami przemysłowymi zlokalizowanymi w różnych miejscach ŁOM oraz możliwość wyprowadzenia ruchu samochodów ciężarowych z dróg leżących wewnątrz Konstantynowa Łódzkiego. W ten sposób ruch pojazdów 
odbywałby się od strony zachodniej do dwóch węzłów drogowych na trasie S14 właśnie tymi obwodnicami, a następnie z węzłów:

- Konstantynów Łódzki poprzez planowaną rozbudowę ulicy Szczecińskiej (od obecnego przebiegu do granic miasta Łodzi) do części północnej Łodzi,

- Łódź-Retkinia poprzez ulicę Maratońską do części południowej Łodzi.

Dodatkowo pojazdy nie będą w stanie zjechać z drogi S14 i na nią wjechać w centralnej części Konstantynowa ze względu na brak węzła drogowego na tym obszarze. W ten sposób ruch pojazdów przejeżdżających przez środkową część Konstantynowa zostanie całkowicie wyeliminowany. Obwodnice mogą być budowane fragmentami z uwzględnieniem możliwości ich finansowania. Parametry poszczególnych odcinków tych obwodnic powinny być określone za pomocą kolejnych badań.

Analizując jednak przygotowane prognozy do 2040 r., można wyciągnąć wniosek, że należy tak zaplanować infrastrukturę, żeby ruch tranzytowy wschód-zachód był przejęty przez proponowane obwodnice. Różnica w liczbie pojazdów pomiędzy punktami 3 a 4 (ryc. 5) stanowi ten ruch, który zatrzymuje się lub wyjeżdża z Konstantynowa Łódzkiego, co oznacza, że po wybudowaniu obwodnic przez środek miasta powinien pozostać tylko ten niewielki ruch oraz samochody komunikacji zbiorowej. W celu wyliczenia proporcji ruchu, który przejęłaby obwodnica północna, przyjęto proporcję obecnego ruchu w punktach 6 i 7. Z przeprowadzonych wyliczeń wynika, że obwodnicą południową pojedzie 36\% pojazdów (wg prognozy w 2040 r. będzie to 7733 pojazdów na dobę), a obwodnicą południową pojedzie 64\% pojazdów (wg prognozy w 2040 r. będzie to 13748 pojazdów na dobę). Prace nad szczegółowym planowaniem parametrów proponowanych obwodnic należy prowadzić z uwzględnieniem nie tylko potrzeb transportowych, ale także innych czynników - ekonomicznych, społecznych i ekologicznych.

\section{Podsumowanie}

W wyniku przeprowadzonych analiz i rozważań w niniejszym artykule sformułowano następujące wnioski:

1. Drogi leżące na terenie Konstantynowa Łódzkiego przenoszą zarówno w układzie wschód-zachód, jak i północ-południe ruch głównie tranzytowy.

2. Przygotowane prognozy ruchu jednoznacznie wskazują na konieczność budowy zarówno drogi S14, jak również dwóch obwodnic miasta przejmujących ruch na kierunku wschód-zachód.

3. Realizacja proponowanych obwodnic oraz pozostałej infrastruktury komunikacyjnej jest uzależniona od budowy drogi S14. Z tego powodu bardzo ważne jest zbudowanie tej drogi możliwie najszybciej.

4. Brak rozbudowy infrastruktury drogowej (S14, proponowane obwodnice oraz pozostałe elementy infrastruktury) lub odkładanie jej w czasie będzie miało poważne skutki w obszarze problemów z logistyką miejską, ekologią, niezadowoleniem społecznym oraz wyhamowaniem wzrostu gospodarczego analizowanego obszaru. 
Przedsięwzięcia budowy infrastruktury transportowej zawsze są bardzo trudne ze względu na ich szeroki zakres i skutki. Jednak bez tych trudnych i długotrwałych inwestycji miasto nie zapewni swoim mieszańcom odpowiednich warunków życia. Należy zatem podjąć wyzwanie budowy niezbędnych elementów infrastruktury transportu zarówno na szczeblu rządowym, jak i samorządowym.

\section{Bibliografia}

Brol R. (red.), 2004, Ekonomika i zarzadzanie miastem, Wydawnictwo Akademii Ekonomicznej we Wroclawiu, Wrocław.

Cheng J., Bertolini L., 2013, Measuring urban job accessibility with distance decay, competition and diversity, "Journal of Transport Geography" 30.

Dembińska-Cyran I., 2006, Sposoby rozwiązywania problemów transportu w zgodzie z zasadami zrównoważonego rozwoju miast (cz. 1.), „Logistyka” nr 6.

Generalny pomiar ruchu w 2010 r., GDDKiA, https://www.gddkia.gov.pl/pl/987/gpr-2010

Komornicki T., 2015, Present and future spatial accessibility of the Polish sea ports, "Bulletin of the Maritime Institute in Gdańsk" 30(1).

Komornicki T., Rosik P., Śleszyński P., Solon J., Wiśniewski R., Stępniak M., Czapiewski K., 2013, Wptyw budowy autostrad $i$ dróg ekspresowych na rozwój społeczno-gospodarczy i terytorialny Polski, opracowanie wykonane przez Instytut Geografii i Przestrzennego Zagospodarowania Polskiej Akademii Nauk na zlecenie Ministerstwa Rozwoju Regionalnego, Warszawa.

Konstantynów Łódzki w liczbach, http://www.polskawliczbach.pl/Konstantynow_Lodzki\#finanse-publiczne (dostęp 28 marca 2018).

Konstantynów, twoje miasto, http://www.polskawliczbach.pl/Konstantynow_Lodzki (dostęp 28 marca 2018).

Kozłowski R., 2011, Wptyw infrastruktury transportu na rozwój klastrów na przykładzie regionu tódzkiego, [w:] Sosnowski J. (red.), Klastry logistyczne na tle procesów rozwoju regionu, Wydawnictwo Uniwersytetu Łódzkiego, Łódź 2011.

Kozłowski R., Marczak M., Sikorski A., Kozal T., Janusz A., Palczewska A., 2014, Raport końcowy projektu Systemowe wsparcie procesów zarządzania w IST - Konstantynów Łódzki.

Marshall S., Banister D. (eds.), 2007, Land use and transport: European research toward integrated policies, Elsevier, Amsterdam.

Natężenie Ruchu z wykorzystaniem Google Maps, Typowe natężenie ruchu w poniedziałek o godz. 07:35 oraz w piątek o godz. 15:25 w centrum miasta na skrzyż. 71 i 710, https://www.google.pl/maps/place/95-050+Konstantyn\%C3\%B3w+\%C5\%81\%C3\%B3dzki/@51.757086,19.2751446,13z/data=!4m5!3m4!1s0x47 1a4ae5535334c7:0x5107b380d9b503ac!8m2!3d51.7476048!4d19.3254913!5m1!1e1?hl=pl

Perenc J., 1994, Próba określenia istoty kosztów zewnętrznych w transporcie, „Zeszyty Naukowe Uniwersytetu Szczecińskiego. Prace Wydziału Transportu i Łączności" nr 5.

Polska w liczbach, http://www.polskawliczbach.pl/Konstantynow_Lodzki (dostęp 28 marca 2018).

Pomiar ruchu na drogach powiatowych powiatu pabianickiego - rok 2013.

Pomiar ruchu na drogach wojewódzkich w 2010 roku.

Rudnicki A., 2010, Zrównoważona mobilność a rozwój przestrzenny miasta, „Czasopismo Techniczne. Architektura" z. 3.

Rzepnikowska M., Mikołajczak R., Antczak R., Barcik A., Wójcik, M., Raport o korkach w 7 największych miastach Polski, Warszawa marzec 2016, Deloitte, http://www2.deloitte.com/pl/pl/pages/public-sector/ articles/korki-w-polskich-miastach.html (dostęp 28 marca 2018).

Statystyczne vademecum samorządowca, Gmina Miejska Konstantynów Łódzki, http://lodz.stat.gov.pl/ vademecum/vademecum_lodzkie/portrety_gmin/pabianicki/miasto_konstantynow_lodzki.pdf (dostęp 28 marca 2018).

Wiśniewski S., 2016, Wpływ budowy południkowych obwodnic Łodzi na dostępność mieszkańców miasta do sieci dróg o najwyższych parametrach, „Rozwój Regionalny i Polityka Regionalna” 34.

Zuziak Z.K., 2008, O tożsamości urbanistyki, Wydawnictwo Politechniki Krakowskiej, Kraków. 